\title{
Vitamin D3 Receptor Staining Method
}

National Cancer Institute

\section{Source}

National Cancer Institute. Vitamin D3 Receptor Staining Method. NCI Thesaurus. Code C122860.

An immunohistochemical technique used to detect the presence of vitamin D3 receptor in a tissue sample. 